\title{
Assessment of menstrual characteristics among nulliparous female consumers of carbonated soft drinks
}

\author{
Ologhaguo M. Adienbo*, Victor O. Hart, Austine A. Ajah
}

Department of Human Physiology, College of Health Sciences, University of Port Harcourt, Port Harcourt, Nigeria

Received: 11 October 2015

Revised: 24 November 2015

Accepted: 12 December 2015

\author{
*Correspondence: \\ Dr. Ologhaguo M. Adienbo, \\ E-mail: ologhaguo.adienbo@uniport.edu.ng
}

Copyright: $(\odot$ the author(s), publisher and licensee Medip Academy. This is an open-access article distributed under the terms of the Creative Commons Attribution Non-Commercial License, which permits unrestricted non-commercial use, distribution, and reproduction in any medium, provided the original work is properly cited.

\begin{abstract}
Background: Soft drinks are consumed in large quantities globally as beverages for refreshment and for social purposes as substitutes or supplements to alcoholic drinks. Health concerns over soft drinks consumption have been severally reported. Aim: This study is aimed at investigating the effect soft drink consumption on the menstrual characteristics of female Nigerians.

Methods: A cross sectional descriptive study of 639 nulliparous females of age range 16-40 years with regular menstruation were randomly selected, comprising $392(61.30 \%)$ who consume carbonated soft drink regularly during menstruation, and $247(38.70 \%)$ who do not. Structured questionnaires were administered to each subject to determine their age and menstrual characteristics (duration, flow, pain and cycle).

Results: The results showed that consumption of soft drinks during menstruation causes an increase in menstrual flow in $85.71 \%$ of consumers; $89.54 \%$ observed an increase in menstrual pain, while $51.53 \%$ reported prolongation in duration of menstrual bleeding. Also, a significant $(\mathrm{p}=0.002)$ increase in the duration of menstrual bleeding, with an insignificant $(\mathrm{p}>0.05)$ increase in menstrual cycle $(\mathrm{p}>0.05)$ were observed among soft drink consumers when compared to non-consumers.

Conclusions: This study has shown that consumption of soft drinks during menstruation could alter menstrual characteristics in nulliparous females by increasing the menstrual flow, menstrual pain and menstrual duration.
\end{abstract}

Keywords: Menstrual characteristics, Menstrual cycle, Soft drink

\section{INTRODUCTION}

Soft drinks are non-alcoholic, usually carbonated, drinks with a sweet bubbly refreshing taste. They contain mainly water, sugar and chemicals in the form of colorings, flavors, preservatives and sweeteners. There has been an overwhelming rise in the global consumption of soft drinks, in particular carbonated beverages, over the recent past decades. They are consumed in large quantities globally as beverages for refreshment, and or for social purposes as substitutes or supplements to alcoholic drinks. They are now the most popular refreshments among much of the world's population and age groups ranging from infants, adolescents, youth to adults. ${ }^{1-3}$ Although considered as fairly innocuous by most people, regular consumption of soft drinks has been associated with several health concerns such as development of cardiovascular disease, diabetes mellitus, dental/bone problems, obesity and formation of kidney stones, ${ }^{4-8}$ as well as a delayed or lower chance of conception., 9 Menstrual characteristics, on the other hand, can be affected by life-style such as cigarette smoking, ${ }^{11}$ caffeine consumption $^{12}$ and alcohol consumption. ${ }^{13}$ This present study was therefore designed to assess the menstrual 
characteristics of subjects that consume soft drink during menstruation.

\section{METHODS}

\section{Study area and population}

This is a cross-sectional descriptive survey carried out from September to December, 2014 in Port Harcourt, Rivers State, Nigeria. A total number of 639 nulliparous female students aged between 16 and 40 years were recruited from the departments of Human Physiology and Biomedical technology, University of Port Harcourt. Respondents were selected from both departments using stratified random sampling method based on their faculty and year of study. University students were chosen for the study because they comprised of girls from diverse ethnic and socioeconomic background.

\section{Inclusion criteria}

Respondents included into the study were nulliparous, have attained menarche at least one year before the date of interview, not on any contraceptive, without any gynaecological disorder, and have regular uninterrupted menstruation for a minimum period of 12 months, from the day of the interview.

\section{Data collection}

A pre-tested questionnaire was administered to subjects to complete. The aim of the study and the contents of the questionnaire were explained to each respondent, and voluntary participation was requested. The questionnaire had questions on present age of participants, consumption of sweetened carbonated soft drinks (coke, fanta and pepsi) during menstruation; menstrual characteristics such as length of cycle (ranging from short, <23 days to long, $>30$ days, relative to 21-35 days normal cycle length) as defined in previous studies; ${ }^{14,15}$ duration of menstrual bleeding; regularity of menstruation; menstrual pain (pain at the time of menstrual discharge), and amount of menstrual flow (depending on a subjective assessment based on the number of pads each subject uses in a day during the bleeding period) was assessed as heavy ( $>3$ pads) or light $(\leq 3$ pads) as previously reported; ${ }^{16,17}$ on the basis of self-reported menstrual history from the baseline questionnaire. The returned questionnaires were analysed using Statistical Package for Social Sciences (SPSS) version 20.0 (SPSS Inc, Chicago, II). Descriptive statistics (frequency, percentage and mean calculation) was applied to compare the menstrual characteristics variables, while students t-test was used, were necessary, to compare different variables for any significant difference (at $\mathrm{p}<0.05$ ). The results were presented in frequency, percentages and mean \pm SD.

\section{RESULTS}

Of the 639 nulliparous females that participated in the study, $40.80 \%$ have age range $21-30$ years; $55.10 \%$ were aged 16-20 years while $4.1 \%$ were $31-40$ years. Also, 392 $(61.30 \%)$ of the total population consume soft drink during menstruation while 247(38.7\%) subjects do not consume soft drink during menstruation (Table 2).

Table 1: Distribution of respondents in the population studied according to their menstrual characteristics.

\begin{tabular}{|c|c|c|}
\hline $\begin{array}{l}\text { Menstrual } \\
\text { characteristic }\end{array}$ & $\begin{array}{l}\text { Number of } \\
\text { subjects }(\mathbf{N})\end{array}$ & $\begin{array}{l}\text { Percentage } \\
(\%)\end{array}$ \\
\hline \multicolumn{3}{|l|}{ Length of cycle (days) } \\
\hline$<23$ & 51 & 8 \\
\hline $23-26$ & 140 & 21.9 \\
\hline $27-30$ & 403 & 63.1 \\
\hline$>30$ & 45 & 7 \\
\hline Total & 639 & 100 \\
\hline \multicolumn{3}{|c|}{ Duration of bleeding (days) } \\
\hline $2-3$ & 98 & 15.3 \\
\hline $4-6$ & 531 & 83.1 \\
\hline$>6$ & 10 & 1.6 \\
\hline Total & 639 & 100 \\
\hline \multicolumn{3}{|l|}{ Menstrual flow } \\
\hline Heavy (>3 pads/day) & 247 & 38.7 \\
\hline Light ( $\leq 3$ pads/day) & 392 & 61.4 \\
\hline Total & 639 & 100 \\
\hline \multicolumn{3}{|l|}{ Menstrual pain } \\
\hline Yes & 441 & 69.00 \\
\hline No & 198 & 31.00 \\
\hline Total & 639 & 100 \\
\hline
\end{tabular}

The menstrual characteristics of the population studied (Table 1) shows that more of the respondents $(63.1 \%)$ have menstrual cycle interval of 27-30 days; $21.9 \%$ have 23-26 days while only $8 \%$ and $7 \%$ of the subjects have $<23$ days and $>30$ days cycle respectively. Although the mean cycle length for those that consume soft drink during menstruation is higher compared to those that do not consume, the difference is statistically not significant $(\mathrm{p}>0.05)$.

Table 2: Mean menstrual duration and menstrual cycle of subjects based on their consumption of soft drink during menstruation.

\begin{tabular}{|llll|}
\hline $\begin{array}{l}\text { Menstrual } \\
\text { characteristics }\end{array}$ & \multicolumn{3}{l}{$\begin{array}{l}\text { Soft drink consumption during } \\
\text { menstruation }\end{array}$} \\
\cline { 2 - 4 } & $\begin{array}{l}\text { Yes } \\
\mathrm{n}=392 \\
(61.3 \%)\end{array}$ & $\begin{array}{l}\text { No } \\
\mathrm{n}=247 \\
(38.7 \%)\end{array}$ & $\begin{array}{l}\text { Total } \\
\mathrm{n}=639 \\
(100 \%)\end{array}$ \\
\hline $\begin{array}{l}\text { Duration of } \\
\text { bleeding (days) }\end{array}$ & $4.45 \pm 0.02 *$ & $4.20 \pm 0.01$ & $4.38 \pm 0.01$ \\
\hline $\begin{array}{l}\text { Length of } \\
\text { cycle (days) }\end{array}$ & $28.86 \pm 6.20$ & $28.25 \pm 3.86$ & $28.56 \pm 4.50$ \\
\hline $\begin{array}{l}* \text { Significant difference }(\mathrm{p}=0.002) \\
\text { of soft drink }\end{array}$ & & & \\
\hline
\end{tabular}


Further, majority of subjects in the population $(83.1 \%)$ have menstrual bleeding duration of 4-6 days while other subjects menstruate for $2-3$ days $(15.30 \%)$ and $>6$ days (1.6\%) respectively (Table 1 ). Majority (51.53\%) of subjects that consume soft drink during menstruation reported an increase in duration of bleeding (Figure 1). The mean menstrual duration for the total population was $4.38 \pm 0.02$ days, with a significant increase $(p=0.002)$ in the duration of bleeding among subjects that consume soft drink, compared to those that do not consume soft drinks (Table 2).

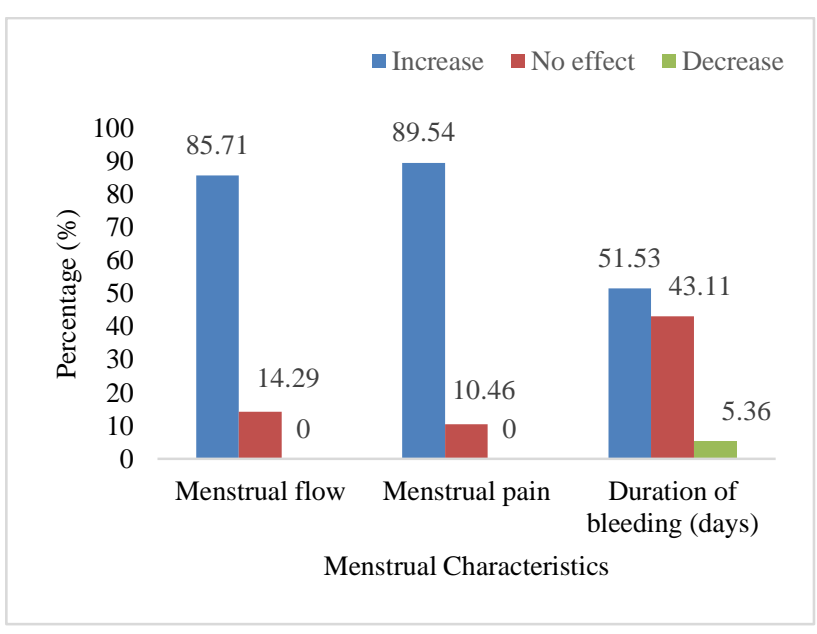

Figure 1: Percentage distribution of subjects consuming soft drink during menstruation according to severity of effect on their menstrual characteristics.

The results of menstrual flow of subjects show that 61.4 $\%$ of the population had light flow, while $38.6 \%$ experienced heavy blood flow (table 1). Among the 392 subjects that usually consume soft drink during menstruation (table 2), majority $(85.71 \%)$ of them reported an increase in menstrual flow (Figure 1). Further, while $61 \%$ of the population experience abdominal pain during menstruation, $89.54 \%$ of the 392 subjects that usually consume soft drink during menstruation reported an increase in menstrual pain (Figure 1).

\section{DISCUSSION}

In this study, majority of respondents reported that consumption of carbonated soft drink during menstruation increases their menstrual flow, menstrual pain and prolong the duration of menstrual bleeding, without altering the menstrual cycle length. Menstrual blood flow is achieved by myometrial contractility, vasoconstriction and haemostatic plug formation. While vasoconstriction and the haemostatic plug formation control the volume of menstrual blood flow; the duration of menstrual bleeding is affected by contraction of the myometrium, vasoconstriction, and haemostatic plug formation mechanisms. The increase in menstrual pain, menstrual flow and duration of bleeding reported by majority of respondents in this study suggests that some components of soft drink may have effect on the uterine contractile and haemostatic mechanisms. For instance, carbonated soft drinks contain several food additives including artificial sweeteners, preservatives (potassium sorbate, ascorbic acid, citric acid and sodium citrate), antioxidants, colorants, and caffeine. ${ }^{18,19}$ Consumption of caffeinated beverages has been reported to increase the caffeine load, ${ }^{20}$ and caffeine has been shown to induce transient contraction of smooth muscles through the release of intracellular calcium from intracellular storage sites. $^{21-23}$ Also, the ascorbic acid component present in soft drink has been reported to have a profound excitatory effect on contractions of aortic smooth muscle, ${ }^{24}$ suggesting contractile effects of soft drink on smooth muscles and blood vessels. Therefore, the uterus, made up of smooth muscles, could contract more easily when there is an increase blood supply rich in these various components of soft drink. This increased contraction could have resulted to the increase in abdominal pain experienced by majority of the respondents, as well as causing a degeneration of the spiral arteries that supply the endometrium resulting to the observed heavy and increased menstrual flow experienced by majority of the respondents. The results from this study is consistent with previous reports, ${ }^{25,26}$ where cigarette smoking has been associated with increased daily amount of menstrual bleeding (heavier menses), and increased duration of menstrual pain, when compared with non-smokers. Although, some studies ${ }^{12}$ have suggested that women who consumed caffeine are less likely to have long menstrual duration, contradicting our observation; however, our observation suggests that when the various components in a carbonated soft drink are taken together, they may have acted differently, by altering some specific systemic effects.

In conclusion, this study has shown that consumption of carbonated soft drinks during menstruation alters the menstrual characteristics by increasing menstrual flow, pain and the duration of menstrual bleeding, without altering the menstrual cycle length. These results suggest that carbonated soft drinks may have effect on the neuroendocrine and reproductive systems in females; and consequently on their functions. Therefore, the pattern and characteristics of menstrual variables could be considered as indicators of reproductive health in females. This necessitates the need for further experimental studies in this direction.

\section{CONCLUSIONS}

This study has shown that consumption of soft drinks during menstruation could alter menstrual characteristics in nulliparous females by increasing the menstrual flow, menstrual pain and menstrual duration.

Funding: No funding sources

Conflict of interest: None declared

Ethical approval: The study was approved by the Institutional Ethics Committee 


\section{REFERENCES}

1. McGartland C, Robson PJ, Murray L, Cran G, Savage MJ, Watkins DC et al. Carbonated soft drink consumption and bone mineral density in adolescence: the Northern Ireland Young Hearts project. J Bone Miner Res. 2003;18:1563-9.

2. Jurgens H, Haass W, Castaneda TR, Schurmann A, Koebnick C, Dombrowski $\mathrm{F}$ et al. Consuming fructose-sweetened beverages increases body adiposity in mice. Obesity Res. 2005,13(7):1146-56.

3. Bankole OO, Aderinokun GA, Odenloye O, Adeyemi AT. Weaning practices among some Nigerian women: implication on oral health. Odontostomatol Trop. 2006;29:15-21.

4. Fung TT, Malik V, Rexrode KM, Manson JE, Willett WC, Hu FB. Sweetened beverage consumption and risk of coronary heart disease in women. Am J Clin Nutr. 2009;89:1037-42.

5. Palmer JR, Boggs DA, Krishnan S, Hu FB, Singer M, Rosenberg L. Sugar-sweetened beverages and incidence of type 2 diabetes mellitus in African American women. Arch Intern Med. 2008;168:148792.

6. Yip HH, Wong RW, Hägg U. Complications of orthodontic treatment: are soft drinks a risk factor? World J Orthod. 2009;10:33-40.

7. Swinburn BA, Caterson I, Seidell JC, James WP. Diet, nutrition and the prevention of excess weight gain and obesity. Public Health Nutr. 2004;7:123-46.

8. Passman CM, Holmes RP, Knight J, Easter L, Pais $\mathrm{V}$, Assimos DG. Effect of soda consumption on urinary stone risk parameters. J Endourol. 2009;23:347-50.

9. Wilcox A, Weinberg C. Tea and fertility. Lancet. 1991;337(8750):1159-60.

10. Hatch EE, Bracken MB. Association of Delayed Conception with Caffeine Consumption. Am J Epidemiol. 1993;138(12):1082-92.

11. Windham GC, Elkin EP, Swan SH. Cigarette smoking and effects on menstrual function. Obstet Gynecol. 1999;93:59-65.

12. Fenster L, Quale C, Waller K. Caffeine consumption and menstrual function. Am $\mathrm{J}$ Epidemiol. 1999;149(6):550-57.

13. Liu Y, Gold EB, Lasley BL, Johnson WO. Factors Affecting Menstrual Cycle Characteristics. Am J Epidemiol. 2004;160:131-40.

14. Olsson H, Landin-Olsson M, Gullberg B. Retrospective assessment of menstrual cycle length in patients with breast cancer, in patients with benign breast disease, and in women without breast disease. J Natl Cancer Inst. 1983;70(1):17-20.

15. Rowland AS, Baird DD, Long S. Influence of medical conditions and lifestyle factors on the menstrual cycle. Epidemiology. 2002;13(6):668-74.
16. Hornsby PP, Wilcox AJ, Weinberg CR, Herbst AL. Effects on the menstrual cycle of in uero exposure to diethylstilbestrol. Am J Obst Gynecol. 1994;170:709-15.

17. Hahn KA, Wise LA, Riis AH, Mikkelsen EM, Rothman KJ, Banholzer $\mathrm{K}$ et al. Correlates of menstrual cycle characteristics among nulliparous Danish women. Clinical Epidemiology. 2013;5:3119.

18. Frazier RA, Inns EL, Dossi N, Ames JM, Nursten HE. Development of a capillary electrophoresis method for the simultaneous analysis of artificial sweeteners, preservatives and colours in soft drinks. J Chromatogr. 2000;876:213-20.

19. Lambert RJ, Stratford M. Weak acid preservatives: modeling microbial inhibition and response. J Appl Microbiol. 1999;86:157-64.

20. Smith S, Swain J, Brown EM, Wyshak G, Albright $\mathrm{T}$, Ravnikar VA et al. A preliminary report of the short-term effect of carbonated beverage consumption on calcium metabolism in normal women. Arch Intern Med. 1989;149:2517-9.

21. Ganitkevich VY, Isenberg G. Contribution of Ca2+induced $\mathrm{Ca} 2+$ release to the $[\mathrm{Ca} 2+] \mathrm{i}$ transients in myocytes from guLambert RJ, Stratford M. Weak acid preservatives: modeling microbial inhibition and response. J Appl Microbiol 86: 157-164inea-pig urinary bladder. J Physiol. 1999;458:119-37.

22. Lee JG, Wein AJ, Levin RM. The effect of caffeine on the contractile response of the rabbit urinary bladder to field stimulation. General Pharmacology. 1993;24(4):1007-11.

23. Sugita M, Tokutomi N, Tokutomi Y, Terasaki H, Nishi K. The properties of caffeine- and carbacholinduced intracellular $\mathrm{Ca} 2+$ release in mouse bladder smooth muscle cells. Eue J Pharmacol. 1998;348(1):61-70.

24. Dillon PF, Root-Bernstein RS, Leider CM. Antioxidant-independent ascorbate enhancement of catecholamine-induced contractions of vascular smooth muscle. Am J Physiol Heart Circ Physiol. 2004;286:H2353-H2360.

25. Mishra GD, Dobson AJ, Schofield MJ. Cigarette smoking, menstrual symptoms and miscarriage among young women. Aust N Z J Public Health. 2000;24(4):413-20.

26. Hornsby PP, Wilcox AJ, Weinberg CR. Cigarette smoking and disturbance of menstrual function. Epidemiology. 1998;9(2):193-8.

Cite this article as: Adienbo OM, Hart VO, Ajah AA. Assessment of menstrual characteristics among nulliparous female consumers of carbonated soft drinks. Int J Reprod Contracept Obstet Gynecol 2016;5:194-7. 